\title{
Plant Layout dan penentuan Critical Control Point Pada proses produksi Ikan

\author{
Cakalang (Katsumonus pelamis) di PT. Samudra Sakti Sepakat Laha-Ambon
}

\section{Anthon Masela}

Sekolah Tinggi Ilmu Ekonomi Saumlaki, anthonmasela@gmail.com

\begin{abstract}
ABSTRAK
Peranan perikanan dalam pembangunan ekonomi cukup besar, baik sebagai penghasil bahan pangan sumber protein maupun sebagai penghasil devisa negara. Salah satu daerah di Indonesia yang memiliki potensi sumberdaya kelautan dan perikanan yang besar adalah Provinsi Maluku. Maluku adalah provinsi kepulauan dengan luas wilayah 712.479,69 km², terdiri dari 92,4 \% luas perairan laut atau sebesar $658.294,69 \mathrm{~km}^{2}$ dibandingkan luas daratan yang hanya $7,6 \%\left(54.185 \mathrm{~km}^{2}\right)$. Kondisi perairan tersebut diperkaya oleh potensi sumberdaya perikanan sebanyak 1.640 .160 ton/tahun. Potensi sumberdaya hayati perikanan dimaksud terdiri dari pelagis, demersal, dan biota laut lainnya yang dapat dimanfaatkan secara optimal. (Dinas Perikanan dan Kelautan Provinsi Maluku,2007). HACCP (Hazard Analysis Critical Control Point) adalah suatu sistem kontrol dalam upaya pencegahan terjadinya masalah yang didasarkan atas identifikasi titik-titik kritis di dalam tahap penanganan dan proses produksi. HACCP merupakan salah satu bentuk manajemen resiko yang dikembangkan untuk menjamin keamanan pangan dengan pendekatan pencegahan (preventive) yang dianggap dapat memberikan jaminan dalam menghasilkan makanan yang aman bagi konsumen. Penelitian ini bersifat deskriptif yaitu mengadakan deskripsi untuk memberikan gambaran yang jelas tentang kondisi nyata subyek penelitian. dan Metode yang digunakan dalam Penelitian ini adalah, Analisis deskriptif kualitatif, yakni Melihat Layout Pabrik dan menghitung tingkat kesediaan produk jadi, Menganalisis Alur Produksi untuk Melihat CCP (titik titik critis), Metode observasi yakni pengamatan langsung di lapangan, degan pengambilan sample adalah Purposive sampling. Hasil identifikasi titik kritis (CCP) berdasarkan hasil Pengamatan dan Penentuan CCP Mengunakan Metode decision tree diketahui bahwa tahap pembekuan, dan Penyimpanan, dinyatakan sebagai titik kritis (CCP). Dalam pemantauan/monitoring CCP Pada PT. Samudara Sakti Sepakat telah menerapkan prosedur, pengendalian titik titik kritis dengan ciri-ciri khusus dan penanganan tersendiri. Faktor utama yang menjadi pertimbangan dalam penentuan lokasi pabrik (plant location) adalah lokasi bahan baku, lokasi pasar, tenaga kerja dan tingkat upah serta air dan limbah industri yang dibuang. Jenis tata letak pabrik (plant layout) yang terdapat pada perusahaan tersebut merupakan produk layout yakni berdasarkan aliran produksi, dikarenakan berbagai faktor, seperti jenis produk yang dibuat hanya satu macam (ikan utuh), diproduksi dalam jumlah besar dan untuk jangka waktu yang relatif singkat, jenis mesin yang digunakan ditujukan untuk komponen yang serupa, serta jenis mesin bersifat special purpose machine, yakni hanya ditujukan untuk fungsi tertentu saja. Mesin-mesin yang digunakan khususnya untuk memproduksi ikan beku bersifat fixed path machine, dan proses produksi bersifat continue process (terjadi terus menerus
\end{abstract}


Kata Kunci: Penentuan HACCP

\section{Pendahuluan}

Peranan perikanan dalam pembangunan ekonomi cukup besar, baik sebagai penghasil bahan pangan sumber protein maupun sebagai penghasil devisa negara.

Salah satu daerah di Indonesia yang memiliki potensi sumberdaya kelautan dan perikanan yang besar adalah Provinsi Maluku. Maluku adalah provinsi kepulauan dengan luas wilayah 712.479,69 $\mathrm{km}^{2}$, terdiri dari $92,4 \%$ luas perairan laut atau sebesar 658.294,69 km² dibandingkan luas daratan yang hanya 7,6 \% (54.185 $\mathrm{km}^{2}$ ). Kondisi perairan tersebut diperkaya oleh potensi sumberdaya perikanan sebanyak 1.640.160 ton/tahun. Potensi sumberdaya hayati perikanan dimaksud terdiri dari pelagis, demersal, dan biota laut lainnya yang dapat dimanfaatkan secara optimal. (Dinas Perikanan dan Kelautan Provinsi Maluku,2007).

Pengolahan hasil perikanan yang memegang peranan penting dalam kegiatan pasca panen, sebab dengan melakukan usaha pengolahan, hasil perikanan sebagai komoditi yang sifatnya mudah rusak dan membusuk dapat ditingkatkan daya awetnya, disamping itu usaha pengolahan juga dapat meningkatkan nilai tambah ( added value ) produk tersebut.

Hasil perikanan merupakan komoditas yang mudah mengalami proses kemunduran mutu dan pembusukan, dimana hal ini terjadi setelah ikan ditangkap. Dengan demikian perlu penanganan yang cepat, tepat dan benar untuk menjaga kualitasnya sebelum dipasarkan dan sampai ke tangan konsumen. Selain itu dari segi ekonomi akan memberikan nilai tambah (value added) terhadap harga jual produk. Hal ini diperlukan saat-saat musim ikan, dimana musim panen ikan sangat murah tetapi permintaan konsumen cenderung stabil/tidak meningkat, sehingga ikan tidak habis dipasarkan dalam keadaan segar.

(Rini Susianawati, 2006).

Pendinginan ikan merupakan salah satu proses yang umum digunakan dalam mengatasi masalah pembusukan ikan, baik 
selama penangkapan, pengangkutan maupun penyimpanan sementara sebelum diolah menjadi produk lain.

Dalam proses pendinginan ikan maka tidaklah luput dari peranan pabrik yang bergerak dalam bidang penyimpanan, mengingat produk perikanan pada dasarnya bersifat musiman, sehingga tidak dapat diperoleh setiap waktu. Secara tidak langsung, pabrik jenis ini dapat menstabilkan harga produk perikanan yang umumnya fluktuatif sesuai musimnya. ( Afrianto dan Liviawanty, 2005 )

HACCP (Hazard Analysis Critical Control Point) adalah suatu sistem kontrol dalam upaya pencegahan terjadinya masalah yang didasarkan atas identifikasi titik-titik kritis di dalam tahap penanganan dan proses produksi. HACCP merupakan salah satu bentuk manajemen resiko yang

\section{TINJAUAN PUSTAKA}

\section{Karakteristik dan Penanganan Produk Perikanan}

Usaha perikanan di bedakan atas perikanan tangkap akuakultur dan pengolahan perikanan. Perikanan tangkap adalah kegiatan memproduksi ikan dengan dikembangkan untuk menjamin keamanan pangan dengan pendekatan pencegahan (preventive) yang dianggap dapat memberikan jaminan dalam menghasilkan makanan yang aman bagi konsumen.

Tujuan dari penerapan HACCP dalam suatu industri pangan adalah untuk mencegah terjadinya bahaya sehingga dapat dipakai sebagai jaminan mutu pangan guna memenuhi tuntutan konsumen. HACCP bersifat sebagai sistem pengendalian mutu sejak bahan baku dipersiapkan sampai produk akhir diproduksi masal dan didistribusikan. Pada beberapa negara penerapan HACCP ini bersifat sukarela dan banyak industri pangan yang telah menerapkannya.

menangkap (capture) dari perairan di daratan (Inland fisheries) maupun perairan laut (marine fishieris). Akuakultur atau budi daya adalah kegiatan memproduksi ikan dalam suatu wadah terkontrol dan berorientasi pada keuntungan. Sedangkan kegiatan pengolahan perikanan berperan dalam memecahkan permasalahan 
karakteristik produk perikanan, baik yang berasal dari penangkapan maupun budidaya, yakni muda busuk (perishable food) dengan memperpanjang umur produk agar tetap layak konsumsi.

Pengolahan perikanan bisa juga berperan dalam menstabilkan (buffer) ketersediaan produk perikanan dipasar. Melalui pengolahan, permasalahan produk perikanan yang bersifat musiman (terutama produk perikanan tangkap), fluktuatif, mudah busuk, voluminous dan membutuhkan penyimpanan khusus dapat diatasi sampai batas-batas tertentu. Dengan demikian, pengolahan perikanan diharapkan bisa menstabilkan harga produk, sehingga mampu memberikan kepastian usaha dengan menampung kelebihan suplai pada musim ikan

(Effendi dan Oktariza, 2000).

Terkait dengan sifatnya yang mudah busuk, ada dua cara penanganan ikan setelah penangkapan, yaitu (Juniarto, 2003) :

a) Menurunkan suhu ikan, dilakukan pada ikan hasil tangkapan di laut. Teknik ini tergantung pada media pendingin yang digunakan. Keberhasilan teknik ini juga tergantung pada stabilitas suhu ikan selama penanganan. Semakin rendah suhu ikan dapat diturunkan dan semakin stabil suhu dipertahankan selama penanganan, akan semakin baikn kualitas ikan. Untuk medapat mutu kesegaran ikan yang maksimal sampai ke tangan pembeli, penanganan harus dilakukan sejak ikan ada diatas kapal.

b) Mempertahankan Ikan tetap hidup, umumnya untuk tujuan pembenihan dan Ikan Hias. Namun, saat ini mulai menambah ke ikan konsumsi, udang maupun kepiting.

\section{Konsep Dasar Pabrik Atau Industri}

Pabrik (Plant/Faktory), merupakan tempat dimana faktor-faktor produksi (manusia, mesin \& peralatan, material, energy, modal, informasi \& sumber daya alam) dikelola bersama-sama dalam suatu sistem produksi guna menghasilkan suatu produk atau jasa secara efektif, efisien dan aman. Pabrik sering disamakan dengan industri. Padahal sebenarnya industri memiliki pengertian yang lebih luas. Pabrik pada dasarnya merupakan salah satu jenis industri yang terutama akan menghasilkan produk jadi (Wignjosoebroto, 2000). Menurut Wignjosoebroto (2000), berdasarkan 


\section{JOURNAL SEKOLAH TINGGI ILMU EKONOMI SAUMLAKI}

ISSN : 2656-3363-VoL.3. NO.1. 2021

aktivitas-aktivitas yang dilakukan, industri dapat diklasifikasikan menjadi :

a. Industri Penghasil Bahan Baku (Primary Raw-Material Industry), yaitu industri yang aktivitas produksinya adalah mengolah sumberdaya alam guna menghasilkan bahan baku maupun bahan tambahan lainnya yang dibutuhkan oleh industri penghasil produk/jasa misalnya industri perminyakan, penangkapan, dan lain-lain.

b. Industri Manufactur (Manufacturing Industries), yaitu industri yang memproses baha baku guna dijadikan bermacam-macam bentuk/model produk, baik produk setengah jadi maupun produk jadi, misalnya industri mesin.

c. Industri Penyalur (Distribution Industries), yaitu industri yang berfungsi menyalurkan barang dari produsen ke produsen lainnya maupun konsumen. Misalnya misalnya industry grading, penyimpanan, sorting, packing, dan lain-lain.

d. Industri Pelayanan/Jasa (Sevices Industry), yaitu industri yang bergerak dibidang pelayanan atau jasa, baik untuk melayani dan menunjang aktivitas industri lain maupun langsung memberikan pelayanan pada konsumen, misalnya bank, jasa angkutan, dan lain-lain.

\section{Manajemen Mutu Berdasarkan} Konsep HACCP.

\section{Pengertian HACCP}

\section{Hazard Analysis Critical Control} poin (HACCP) mengandung dua kata kunci yaitu :

* Hazard Analysis (Analisis Bahaya).

* Critical control points (titik-titik pengendalian kritis).

Secara umum HACCP diartikan sebagai suatu system manajemen mutu dengan menekankan pada keamanan khusus untuk makanan yang didasarkan pada pendekatan sistemik untuk mengantisipasi kemungkinan terjadinya resiko bahaya (hazard) selama proses produksi serta menentukan titik-titik pengendalian kritis (Critical Contol Points) yang harus dilakukan pengawasan secara ketat.

Dengan kata lain HACCP dapat diartikan sebagai suatu system control dalam upaya pencegahan terjadinya maslah yang didasarkan atas identifikasi titik 
pengendalian kritis (Critial Control Points)

didalam tahapan penanganan dan pengolahan dimana kegagalan dapat menyebabka suatu resiko bahaya (Hazard Risk).

HACCP mengfokuskan kepada tindakan pengawasan dan pengendalian keamanan pangan, yaitu mengidentifikasi dan meneliti bahan yang dianggap berbahaya. (Hazard) dan tahapan proses yang dicurigai sebagai tempat terjadinya pengaruh yang merugikan ( titik critis atau CCP ) dan kemudian melakukan pengawasan/inpeksi pada titik-titik kritis dengan saksama serta mengadakan upaya pencegahan terhadap kemungkinanan terjadinya hal-hal yang merugikan karena bahaya tersebut.

Tujuan dari penerapan HACCP dalam suatu industry pangan adalah untuk mencegah terjadinya bahaya sehingga dapat dipakai sebagai jaminan mutu pangan guna memenuhi tuntutan konsumen . beberapa keuntugan yang dapat diperoleh suatu industry pangan dengan menerapkan sistem HACCP antara lain meningkatkan keamanan pangan pada proksuk makanan yang dihasilkan, meningkatkan kepuasan konsumen sehinggan keluhan konsumen akan berkurang.

Filosofi HACCP :

1. Cegah bahaya

2. Hilangkan bahaya

3. Kurangi bahaya sampai ke level aman

\section{Prinsip HACCP pada Makanan}

Untuk menjamin keamanan suatu produk pangan, NACMCF (1990) menetapkan tujuh (7) prinsip, HACCP sebagai berikut:

1. Analisa bahaya (hazard) dan penetapan resiko yang berhubugan dengan pertumbuhan, pemanenan, bahan mentah dan ingredient, pengolaan pangan, distribusi, penjualan, persiapan dan konsumsi.

2. Penetapan titik pengendalian kritis $(\mathrm{CCP}=$ critical control point $)$ yang dibutuhkan untuk mengendalikan bahaya yang mungkin terjadi.

3. Penetapan limit kritis yang harus dipeuhi untuk CCP yang ditentukan.

4. Penetapan prosedur untuk memantau CCP.

5. Penetapan tindakan korekasi yang harus dilakukan jika terjadi penyimpanan selama pemantauan. 
6. Penatapan sistem pencatatan yang efektif yang merupakan dokumen penting program HACCP.

7. Penetapan prosedur verifikasi untuk membuktika bahwa system HACCP telah berhasil atau masik efektif.

\section{Tim HACCP}

Tim HACCP haruslah terdiri dari orang-orang yang (SUBDITPM. 2004) :

1. Mengerti tentang Hazard biologi, kimia dan fisika yang berhubngan dengan produk.

2. Memiliki pengetahuan kerja yag baik tentang teknik proses-proses dalam penanganan/pengolahan dalam pabrikan serta tahu pasti segala sesuatu yang terjadi di dalamnya.

3. Tenaga teknis memiliki pengetahuan yang baik tentang syarat-syarat hygene proses pengolahan baik peralatan maupun unit pengolahan.

4. Memiliki pengetahuan khusus lainya :
$\checkmark$ Mikrobiologi
$\checkmark$ Hygiene
$\checkmark$ Teknologi pangan

$\checkmark$ Konstruksi unit pengolohan

$\checkmark$ Pemeliharaan

$\checkmark$ Kebutuhan pasar

\section{Metode penelitian}

\section{Metode Penelitian}

Penelitian ini bersifat deskriptif yaitu mengadakan deskripsi untuk memberikan gambaran yang jelas tentang kondisi nyata subyek penelitian. dan Metode yang digunakan dalam Penelitian ini adalah :

Analisis deskriptif kualitatif, yakni Melihat Layout Pabrik dan menghitung tingkat kesediaan produk jadi.

$>$ Menganalisis Alur Produksi untuk Melihat CCP (titik titik critis)

Metode observasi yakni pengamatan langsung di lapangan, degan pengambilan sample adalah Purposive sampling.

Metode dasar yang digunakan dalam Penelitian ini adalah metode deskriptif, dengan tujuan menggambarkan atau melukiskan keadaan subjek/objek penelitian (seseorang, lembaga, dan lain) pada saat sekarang berdasarkan fakta-fakta itu pada tahap permulaan tertuju pada usaha mengemukakan gejala-gejala secara 
lengkap tentang aspek yang diselidiki, agar jelas keadaannya.

(Nawawi, 2005).

\section{Jenis dan Sumber Data}

Jenis data yang digunakan berupa data text (penjelasan) serta data image (gambar). Data yang bersumber di peroleh dari data primer (primary data) dan data sekunder (secondary data). Data primer di peroleh langsung dari sumber utama di lokasi penelitian. sedangkan data sekunder diproleh dari instansi-instansi terkait serta bahan-bahan pustaka lainnya yang dapat menunjang kegiatan Penelitian.

\section{Metode Analisa Data}

Dalam menentukan titik-titik kritis digunakan analisa pengambilan keputusan dengan menggunakan “decision tree". Decision tree merupakan suatu set alat pengambilan keputusan yang terdiri dari pertanyaan-pertanyaan untuk menentukan titik-titik kritis dalam suatu proses pengolahan bahan pangan. Ada empat pertanyaan dalam setiap keputusan mengenai penentuan titik kritis (Codex, 1997) Bagan alir dari decision tree untuk proses pengolahan bahan pangan dapat dilihat pada gambar 3 .
Q1: Apakah pada tahap ini atau tahap lanjutan dalam alur proses, dapat dilakukan tindakan pencegahan untuk jenis bahaya yag ada?

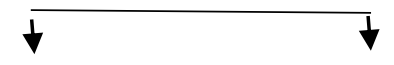

$$
\begin{aligned}
& \text { Jika YA: } \quad \text { Jika TIDAK } \longrightarrow \\
& \text { Bukan CCP } \longrightarrow \text { Stop }
\end{aligned}
$$

Q2: Apakah tahap ini menghilangkan atau menekan kemungkinan terjadinya jenis bahaya hingga mencapai ambang batas yang dapat diterim?

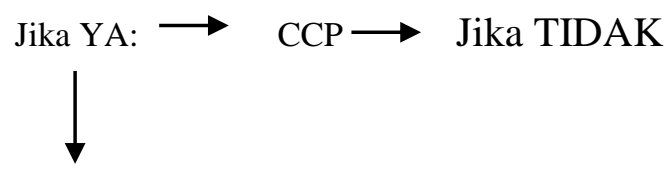

Q3: Dapatkah kontaminasi timbul hingga melebihi batas atau dapatkah kontaminasi meningkat hingga mencapai batas ambang?

Jika TIDAK $\longrightarrow$ Bukan $\mathrm{CCP} \longrightarrow$

Jika YA<smiles>[13CH3]</smiles>

Q4: Apakah tahap lanjutan menghilangkan bahayayang ditetapkan atau menekan kemungkinan munculnya bahaya hingga mencapai amabang batas yang dapat diterima? $\longrightarrow$ Jika TIDAK $\longrightarrow$ $\mathrm{CCP}$ 


\section{Jika YA $\longrightarrow$ Bukan CCP}

\section{Gambar 3. Decision Tree}

Data yang telah diperoleh kemudian diolah dengan menggunakan analisis deskriptif kualitatif.

Analisis deskriptif kualitatif meliputi:

Deskripsi tata letak pabrik, baik tata letak mesin/fasilitas maupun tata letak buruh/karyawan sesuai departemennya masing-masing.

Menentukan titik - titik kritis pada setiap rantai produksi.

Analisis kuantitatif terkait dengan hasil analisa Laboratorium terhadap Beberapa Tahapan Yang Diangap Critical Control point akan di ambil sampel dan di analisa Mikrobiologinya.

\section{Uraian Pelaksanaan penelitian}

Uraian pelaksanaan Penelitian memberikan pegangan yang jelas dalam melakukan penelitian,selain juga merupakan syarat mutlak yang dapat memperjelas sifat penelitian yang dilakukan. Dalam uraian ini juga berhubungan dengan tujuan penelitian yang jadi kerangka dasar penelitian adalah :
Melihat Tipe Tata letak (Plant Layout) dan Mendeskripsikan Tipe tata letak (Layout) Berdasarkan Pola aliran bahan (Material Handling) dengan cara pengamatan terhadap desain tata letak pabrik yang sesuai dengan pala aliran bahan (Material Handling)

$\checkmark$ Mengamati proses Produksi ikan Cakalang dan membuat diangram alirnya yang di kerjakan oleh karyawan perusahan PT Samudra Sakti Sepakat Laha Ambon

$\checkmark$ Melakukan analisis bahaya pada setiap ranatai produksi.

$\checkmark$ Menentukan CCP pada setiap tahap proses produksi yang di lakukan berdasarkan pohon keputusan (decision Tree) yaitu menjawab pertanyaan pertanyaan pada pohon keputusan sehinga dapat ditentukannya CCP

$\checkmark$ Melihat tingkat penerapan critical control point (CCP) mengunakan pohon keputusan setiap proses produksi ikan beku

$\checkmark$ Untuk CCP yang berhubungan dengan bahaya nyata mikrobiologis, penentuannya dapat dipertegas lagi dengan cara melakukan pengujian kandungan bakteri pada bahan/produk saat diduga CCP dan sesudah CCP. 


\section{Penentuan Lokasi Pabrik (Plant Location)}

Faktor utama yang berperan penting dalam penentuan lokasi pabrik PT. Samudra Sakti Sepakat Laha Ambon adalah :

a) Lokasi Sumber Bahan Baku.

Setiap perusahaan yang memproduksikan produk akan senantiasa memerlukan bahan baku untuk kepetingan proses produksi dalam perusahaan yang bersangkutan dan harus berdekatan degan tempat pendaratan ikan atau pelabuhan bagi armada penangkapan perusahaan berlabuh, sehingga akan lebih mempermudah proses pengangkutan dan pembongkaran untuk proses selanjutnya. Propinsi Maluku yang sebagian besar wilayahnya di dominasi oleh perairan, menyebabkan banyaknya perusahaan perikanan dibangun di sini. Hal ini karena sangat berdekatan dengan bahan baku. Jenis bahan baku yang dihasilkan oleh perusahaan ini adalah Pure Material, yang artinya bahan baku tersebut tidak kehilangan persentase volume selama dan setelah proses produksi berlangsung (Ikan masih dalam keadaan utuh).

b) Lokasi Pasar Produk Perusahaan

Pabrik, sebagai tempat dari fungsi teknis suatu perusahaan berada, tidak dapat dipisahkan degan masalah lokasi pasar, untuk produk perusahaan. PT. Samudra Sakti Sepakat Laha Ambon, memiliki lokasi yang strategis karena berdekatan dengan pusat pasar di kota Ambon, sehingga hasil produk ikan beku dapat dipasarkan di kota Ambon dengan mudah, selain itu juga dapat dipasarkan di luar kota Ambon seperti Bali dan Pulau Jawa.

c) Fasilitas Transportasi

Tersedianya fasilitas transportasi merupakan masalah yang sangat penting di dalam menujang proses pengangkutan bahan baku dan para karyawan dalam perusahaan juga membutuhkan transportasi. Sarana transportasi roda empat Milik PT. Samudra Sakti Sepakat Laha Ambon, berjumlah 2 buah Pick-Up pengangkut, sebagai sarana dalam mempercepat proses pengangkutan bahan baku maupun es yang dibutuhkan oleh armada penangkap 
yang hendak beroperasi, serta dalam proses pemasaran produk ikan beku.

d) Tersedianya Tenaga Kerja

Tenaga Kerja merupakan salah satu masukan (input) yang cukup penting di dalam pelaksanaan proses produksi, sehingga tersedianya tenaga kerja ini perlu di perhatikan.

Tenaga kerja terdiri dari tenaga kerja tetap (50 orang) dan tenaga kerja lepas (70 orang dibagian processing). Sebagian besar berpendidikan terakhir SMA. Tenaga kerja lebih mudah diperoleh dari lokasi ini, karena hampir keseluruhannya tinggal di Dusun Air Manis, dekat dengan lokasi pabrik. Sistem pemberian upah/gaji didasarkan pada jumlah hari kerja masing-masing orang pada perusahaan, dengan jumlah upah sebesar Rp. 35.000./hari untuk Wanita dan Rp. 45.000.-/ hari untuk Pria.

e. Air dan Limbah Industri

Ketersediaan air bersih juga turut mempengaruhi penentuan lokasi. Air yang digunakan bersumber dari sumur bor, dengan kedalaman 25-30 m. Limbah yang terdapat pada perusahaan ini adalah berupa air buangan hasil produksi, yakni air hasil cucian sebelum dibekukan dalam Air Blast Frezeer, maupun air rendaman ikan dalam Brine Fish, serta limbah hasil operasional lainnya (misalnya dari bagian bengkel). Saluran pembuangannya menuju ke laut.

\section{Tata Letak Pabrik (Plant Layout)}

Berdasarkan fasilitas-fasilitas yang ada, maka tipe tata letak yang ada pada PT. Samudra Sakti Sepakat tersebut merupakan tipe tata letak berdasarkan aliran produksi (Product Layout). Semua fasilitas dibuat berdasarkan aliran/proses produksi yang berlangsung. Fasilitas-fasilitas ditempatkan berdasarkan fungsi-fungsinya. Bahan baku akan dipindahkan dari satu operasi ke operasi berikutnya. Pada tipe tata letak ini :

1. Hanya ada satu produk yang dibuat, yakni ikan beku utuh (Whole Frozen Fish).

2. Produk dibuat dalam jumlah besar untuk jangka waktu yang relatife lama.

3. Satu mesin hanya digunakan untuk satu jenis operasi, dengan jenis komponen yang serupa. Misalnya, ABF dikhususkan untuk 
membekukan ikan dengan ukuran $<1$ $\mathrm{kg}$, sedangkan BF dikhususkan untuk membekukan ikan dengan ukuran $\geq 1$ $\mathrm{kg}$.

4. Mesin produksi (ABF, BF, Cold Storage) bersifat Special Purpose, artinya hanya digunakan untuk fungsi tertentu saja, dalam hal ini membekukan dan produk. Mesin dan peralatannya ada yang bersifat Fixed Path Machine, artinya bersifat tetap, tidak dapat dikeluarkan dari dalam pabrik seperti fasilitas $\mathrm{ABF}, \mathrm{BF}$ dan Cold Storage, dan ada yang bersifat Variath Path Machine, yang dapat dikeluarkan dari pabrik, seperti peralatan bengkel.

Tata letak ini juga membentuk suatu garis mengikuti jenjang proses pengerjaan produksi produk (ikan beku utuh) dari awal sampai akhir. Tata letak bertipe Product Layout memiliki beberapa keuntungan, yakni :

a. Layout sesuai dengan urutan proses, sehingga alur proses produksi berbentuk garis.

b. Total waktu produksi per unit menjadi pendek, karena alur yang berbentuk garis tersebut, dan mesin dapat ditempatkan pada jarak minimal.

c. Aktivitas selama proses produksi sedikit.

Namun, tipe tata letak ini juga memiliki kelemahan, antara lain :

a. Kerusakan pada satu mesin akan mengganggu kelangsungan proses produksi.

b. Kecepatan produksi tergantung dari mesin yang beroperasi paling hemat.

c. Layout ditentukan berdasarkan produk yang dihasilkan. Perubahan desain produk mengakibatkan terjadinya Relayout.

(Hidayat, 2003).

\section{Pola Aliran Pemindahan Bahan (Material Handling )}

Penangan bahan (Material Handling) adalah kegiatan mengangkat, mengangkut dan meletakkan bahanbahan/barang-barang dalam proses di dalam pabrik, kegiatan yang mana dimulai dari sejak bahan-bahan masuk atau diterima di pabrik sampai pada barang jadi/produk akan dikeluarkan dari pabrik.

Jenis-jenis material handling yang digunakan sebagai berikut

- Untuk aliran bahan dari pembongkaran (di palka kapal penampung) ke sortasi 
dan grading (dalam pabrik), atau dari proses 1 ke proses 2 dan 3 digunakan alat angkut, untuk mengangkut bahan dari dermaga ke dalam pabrik.

- Dalam proses sortasi dan grading (proses 2 dan 3) ke proses timbang (4) digunakan material handling berupa timbangan dan loyang.

- Dari proses timbang (4) ke proses pembekuan (5) Kedalam ABF dan BF, digunakan material handling berupa pan untuk mengatur ikan per $10 \mathrm{~kg}$ serta troli untuk mengangkutnya ke dalam $\mathrm{ABF}$ dan $\mathrm{BF}$.

- Setelah beku, dilanjutkan ke proses glazing atau pencucian (6), menggunakan selang air.

- Setelah proses glazing (6) ke packing (7), digunakan material handling berupa meja kerja stynless steel dan fasilitas pengepakan yang diperlukan, yakni karton (per $10 \mathrm{~kg}$ ) maupun karung (per $35 \mathrm{~kg}$ ).

- Selanjutnya produk yang telah dipacking sesuai ukuran disimpan dalam cold storage (proses 8), menggunakan troli untuk mengangkutnya ke dalam cold storage. Produk siap dikirim sesuai permintaan.
Alur produksi pada perusahaan ini dapat dijelaskan sebagai berikut. Pada saat armada penangkapan mendaratdi dermaga perusahaan, maka dilakukan pembongkaran palka, khususnya untuk kapal penampung, dan ikan-ikan hasil tangkapan dibawah ke dalam pabrik. Selanjutnya, dilakukan sortasi menurut jenis, berat dan kualitas, dilanjutkan dengan pengelompokkan kedalam kelas-kelas tertentu..

Hal yang terjadi adalah biasanya terjadi pemborosan dalam pembiayaan hal ini di karenakan beberapa factor yakni:

a. Adanya kelambatan aliran atau jalannya bahan-bahan yang sedang atau akan dikerjakan dalam proses produksi, Misalnya; Sarana transportasi yang di butukan untuk mengangkut Bahan Baku Tidak Memadai, dalam hal ini Jumlah Bahan Baku lebih Besar dari jumlah Sarana Transportasi.

b. Sering di handle-nya hasil-hasil proses tambahan (by-product) dan barangbarang sisa (srap) secara tidak efisien.

c. Sering dibutuhkannya waktu yang lama untuk memindahkan bahan-bahan atau barang-barang di tempat-tempat pengiriman, penerimaan dan 
pemeriksaan atau pengecekan, yang disebabkan karena tempat tersebut tidak diatur dengan baik.

d. Adanya pemborosan dalam menghandle bahan-bahan di bagian pemeliharaan (maintenance department), yang disebabkan kurangnya pengawasan langsung (direct supervision) dalam menyusun barang-barang dan memindahkan bahan-bahan atau barang-barang.

\section{P e m a s a r a}

Produk ikan beku utuh (whole frozen fish) perusahaan ini dipasarkan ke pasar lokal, regional. Pasar tujuan lokal adalah daerah di dalam Pulau Ambon, baik dibeli oleh pedagang pengumpul lokal ataupun pengecer untuk dijual kembali, maupun untuk diolah menjadi ikan asap. Untuk pasar tujuan Regional, produk biasanya dikirim ke Surabaya dan Jakarta, yang juga berfungsi sebagai pedagang besar (grosir), mengumpulkan produk dari berbagai cabang di Indonesia.

Untuk pemasaran lokal, biasanya para pedagang yang memerlukan ikan akan datang langsung ke pabrik untuk membeli ikan.
Sitem pemasaran pada PT. Samudra Sakti Sepakat Laha Ambon terdiri dari:

- MC (Master Cartoon), dengan ukuran $10 \mathrm{~kg}$.

○ Karung, dengan ukuran $35 \mathrm{~kg}$.

- Container/ekspedisi untuk dengan ukuran 18 ton.

Penjualan produk perusahaan disesuaikan dengan kegiatan sortasi dan grading yang telah dilakukan. Ini berarti bahwa harga produk yang dijual berbeda tiap ukuran dan kualitasnya, sebagaimana yang tertera pada tabel di bawah ini.

Daftar Harga Produk Ikan Beku Utuh PT.Samudra Sakti Sepakat

(Berdasarkan kualitas)

\begin{tabular}{|c|c|c|c|}
\hline Jenis Ikan & Kualitas & $\begin{array}{c}\text { Ukuran } \\
(\mathrm{Kg})\end{array}$ & $\begin{array}{l}\text { Harga } \\
\text { (Rp.) }\end{array}$ \\
\hline \multirow{7}{*}{$\begin{array}{c}\text { C A K A L } \\
\text { A N G }\end{array}$} & \multirow{4}{*}{$\begin{array}{c}\text { Canning } \\
(\mathrm{CN})\end{array}$} & $\begin{array}{c}1- \\
\text { Down }\end{array}$ & 10.000 \\
\hline & & $1,1-1,7$ & 12.500 \\
\hline & & $1,8-2,4$ & 12.000 \\
\hline & & $2,5-U p$ & 11500 \\
\hline & \multirow{3}{*}{ Lokal } & $\begin{array}{c}1- \\
\text { Down }\end{array}$ & 9.500 \\
\hline & & $1,1-1,7$ & 11.000 \\
\hline & & $1,8-2,4$ & 11.500 \\
\hline
\end{tabular}




\begin{tabular}{|c|c|c|c|}
\hline & \multicolumn{2}{|c|}{ Reject } & 5.500 \\
\hline \multirow{4}{*}{$\begin{array}{l}\text { BABY } \\
\text { TUNA }\end{array}$} & \multirow{2}{*}{$\begin{array}{c}\text { Canning } \\
(\mathrm{CN})\end{array}$} & $\begin{array}{c}1- \\
\text { Down }\end{array}$ & 10.500 \\
\hline & & $1,1-1,4$ & 12.000 \\
\hline & \multirow[t]{2}{*}{ Lokal } & $\begin{array}{c}1- \\
\text { Down }\end{array}$ & 9.000 \\
\hline & & 1,1-Up & 10.000 \\
\hline & \multicolumn{2}{|c|}{ Reject } & 5.500 \\
\hline \multirow{2}{*}{$\begin{array}{l}\text { TONGKOL } \\
\text { (DEHO) }\end{array}$} & \multicolumn{2}{|c|}{ Lokal } & 8.000 \\
\hline & \multicolumn{2}{|c|}{ Reject } & 7.500 \\
\hline \multirow{2}{*}{$\begin{array}{l}\text { LAYANG } \\
\text { (MOMAR) }\end{array}$} & \multicolumn{2}{|c|}{ Lokal } & 8.500 \\
\hline & \multicolumn{2}{|c|}{ Reject } & 8.500 \\
\hline
\end{tabular}

\section{Penentuan Critical Control Point}

\section{Identifikas Bahaya}

Dengan Indetifikasi Bahaya ini maka jenis-jenis mikroorganisme, bahan kimia dan benda asing ( Fisik ) dapat di identifikasi. Untuk dapat melakukan ini, Maka harus memeriksa karakteristik produk serta bahaya yang akan timbul sebelum dikonsumsi oleh konsumen.

Terdapat tiga bahaya (hazard) yang dapat menyebabkan makanan menjadi tidak aman untuk dikonsum si, yaitu hazard fisik, kimia, dan biologi.

Bahaya fisik termasuk benda benda seperti pecahan logam, gelas, batu, yang dapat menimbulkan luka di mulut,

\section{ISSN : 2656-3363 - VoL.3. NO.1. 2021}

gigi patah, tercekik ataupun perlukaan pada saluran pencernakan.

Bahaya kimia antara lain , pembersih Lantai, logam berat yang berasal dari perairan.

Bahaya biologi antara lain mikroba patogen (parasit, bakteri).

Selain itu hal-hal penting yang perlu dipertimbangkan adalah:

a. Formulasi; adalah bahan mentah dan bahan baku yang dapat mempengaruhi keamanan dan kestabilan produk.

b. Proses; adalah parameter proses pengolahan yang dapat mempengaruhi bahaya.

c. Kemasan; adalah perlindungan terhadap kontaminasi ulang dan pertumbuhan mikroorganisme

d. Penyimpanan/penanganan; adalah waktu dan kondisi suhu serta penanganan di Cold storage

Semua faktor ini harus dipertimbangkan untuk menentukan risiko serta tingkat bahaya yang dikandungnya.

\section{Pengendalian Titik Critis / Critical}

Control Point (CCP) Proses

Pengolahan Ikan Cakalang Beku pada PT.Samudra Sakti Sepakat 
Titik kendali kritis adalah suatu tahapan dimana dapat dilakukan pengendalian dan esensial untuk mengeliminasi atau menurunkan bahaya keamanan pangan hingga tingkat yang dapat diterima (tidak membahayakan). Identifikasi titik kendali kritis yang sempurna dan akurat sangat mendasar dalam pengendalian bahaya keamanan pangan. Salah satu cara untuk memudahkan identifikasi titik kendali kritis adalah dengan menggunakan $\mathrm{CCP}$ Decision Tree.

Titik kendali kritis terletak pada suatu tahapan dimana bahaya dapat dicegah, dieliminasi atau diturunkan hingga tingkat yang dapat diterima. Contoh titik kendali kritis misalnya proses, Pembekuan, pengujian bahan terhadap residu bahan kimia, pengendalian formulasi produk, dan pengujian produk terhadap kontaminasi Mikroba. Titik kendali kritis harus dikembangkan secara hati-hati dan terdokumentasi, dengan tujuan untuk keamanan pangan

Untuk menentukan titik- titik kritis dalam pengolahan ikan cakalang beku pada PT. Samudra Sakti Sepakat dilakukan dengan menggunakan metode Decision Tree yang merupakan suatu set alat pengambilan keputusan yang terdiri dari pertanyaan-pertanyaan untuk menentukan titik-titik kritis dalam suatu proses pengolahan bahan pangan.

Dari pengamatan dan observasi yang dilakukan serta hasil pengolahan data menggunakan Decision Tree diketahui bahwa CCP dari pengolahan ikan cakalang beku tersebut adalah sebagai berikut :

CCP pada proses pengolahan Ikan Cakalang beku di PT. Samudra Sakti Sepakat teridentifikasikan pada proses tahapan pengolahan. :

1. Tahapan pembekuan :

a. Terdapat tindakan pengendalian (Q1);

b. Pada Tahap lanjutan menghilangkan bahaya yang ditetapkan atau menekan kemungkinan munculnya bahaya hingga mencapai ambang batas yang dapat diterima? (Q4)

Kesimpulan pada tahap pembekuan adalah CCP.

2. Tahapan penyimpanan :

a. Terdapat tindakan pengendalian (Q1);

b. Tahapan dirancang spesifik untuk menghilangkan atau mengurangi 
bahaya yang mungkin terjadi sampai tingkatan yang dapat diterima (Q2). Kesimpulan pada tahap penyimpanan adalah CCP.

\section{Kesimpulan}

Kesimpulan yang dapat diambil dari hasil penelitian ini antara lain adalah :

1. Hasil identifikasi titik kritis (CCP) berdasarkan hasil Pengamatan dan Penentuan CCP Mengunakan Metode decision tree diketahui bahwa tahap pembekuan, dan Penyimpanan, dinyatakan sebagai titik kritis (CCP).

2. Dalam pemantauan/monitoring CCP Pada PT. Samudara Sakti Sepakat telah menerapkan prosedur, pengendalian titik titik kritis dengan ciri-ciri khusus dan penanganan tersendiri.

3. Faktor utama yang menjadi pertimbangan dalam penentuan lokasi pabrik (plant location) adalah lokasi bahan baku, lokasi pasar, tenaga kerja dan tingkat upah serta air dan limbah industri yang dibuang.

4. Jenis tata letak pabrik (plant layout) yang terdapat pada
ISSN : 2656-3363 - VoL.3. NO.1. 2021

perusahaan tersebut merupakan produk layout yakni berdasarkan aliran produksi, dikarenakan berbagai faktor, seperti jenis produk yang dibuat hanya satu macam (ikan utuh), diproduksi dalam jumlah besar dan untuk jangka waktu yang relatif singkat, jenis mesin yang digunakan ditujukan untuk komponen yang serupa, serta jenis mesin bersifat special purpose machine, yakni hanya ditujukan untuk fungsi tertentu saja. Mesin-mesin yang digunakan khususnya untuk memproduksi ikan beku bersifat fixed path machine, dan proses produksi bersifat continue process (terjadi terus menerus).

\section{S a r a n}

Dari hasil dan kesimpulan penelitian ini, untuk memacu perkembangan dan peningkatan pelaksanaan konsep CCP ( Critical Control Point) pengolahan ikan Pada PT Samudra Sakti Sepakat, disarankan sebagai berikut, :

1. Khusus untuk penanganan/pengolahan makanan termasuk hasil perikanan yang 
didasarkan pada pendekatan DAFTAR PUSTAKA

sistematika untuk mengantisipasi kemungkinan terjadinya bahaya (hazard) selama proses produksi dengan menentukan titik kritis yang harus diawasi secara ketat.

Afrianto, E., E. Liviawaty. 2005. Pengawetan Dan Pengolahan Ikan. Kanisius,

2. Suatu proses Produksi Berjalan sesuai Prosedur apabila semua CCP dapat dikontrol dengan baik sehingga tidak terjadi penyimpangan terhadap batas kritis yang telah ditetapkan. Dalam hal penyimpangan terhadap batas kritis harus segera dilakukan upaya perbaikan, semua kegiatan yang dilaksanakan harus di Monitoring dengan baik.

3. Perlu adanya perluasan lokasi pabrik ke depan guna mengekfektifkan Kegiatan Produksi pada setiap departemen sesuai pola aliran bahan (Material Handling). Dan diharapkan adanya Penelitian lanjutan terkait dengan Tata Letak Pabrik dan Sistem Penerapan HACCP yang diterapakan pada PT. Samudra Sakti Sepakat.

Yogyakarta.Harborne, J., 1996. ; Kristanti 2008., Metode fitokimia : Penutun Cara Modern Menganalisis Tumbuhan. Cetakan Kedua. Penerjemah Padmawinata, K dan I.Soediro.Bandung :Penerbit ITB

AG. B. Nuryani, 2006, Tesis ,.pengendalian mutu dan penaganan udang beku dengan Konsep HACCP, Studi Kasus di Kota Semarang dan Kabupaten Cilacap, Universitas diponegoro.

A Tjahjanto Prasetyono,2000. Implementasi GMP dan HACCP dalam Menunjang Quality Assurance Industri Pangan,Jurnal Teknologi Industri Vol. IV No. 3 Juli : 187- 194Januar, Sieburth, J. and J.T. Conover, 1965 ulva an antibiotic which retards fouling. Nature, 208 : 52-53 r 2015) 
Codex Alimentarius, 1997. HACCP System and guidelines for its Application, Annex to CACRCP I 1969 page 3 in Codex Alimentarius. Food Hygiene. Junianto. 2003. Teknik Penanganan Ikan. Penebar Swadaya, Jakarta.

Rini Susianawati, 2006. Tesis, Kajian penerapan GMP dan SSOP pada produk ikan asin kering dalam Upaya peningkatan keamanan pangan di Kabupaten Kendal, Universitas Diponegoro.

Wignjosoebroto, S. 2000. Tata Letak Pabrik dan Pemindahan Bahan. Guna Widya, Surabaya.

Winarno, F.G., S. Fardiaz, D. Fardiaz. 1980. Pengantar Teknologi Pangan. PT. Gramedia. Jakarta 
